\title{
The Effect of Mixing During Laboratory Fermentation of Maize Straw with Thermophilic Technology
}

\author{
Kamil Kozłowski', Jakub Mazurkiewicz', Dawid Chełkowski', Aleksandra Jeżowska', \\ Marta Cieślik², Michał Brzoski ${ }^{1}$, Anna Smurzyńska', Yin Dongmin ${ }^{3}$, Qiao Wei ${ }^{3}$ \\ 1 Institute of Biosystems Engineering, Poznan University of Life Sciences, Wojska Polskiego No. 50, \\ 60-637 Poznan, Poland \\ 2 Department of Biotechnology and Food Microbiology, Poznan University of Life Sciences, Wojska Polskiego \\ No. 48, 60-637 Poznan, Poland \\ ${ }^{3}$ China Agriculture University, Collage of Engineering, Haidian District No. 17, Beijing, China \\ * Corresponding author's e-mail: kamil.kozlowski@up.poznan.pl
}

\begin{abstract}
The interest in biogas production in Poland is growing rapidly. This is mostly due to the fact that there is a need for handling and managing the increasing quantities of diverse bio-waste generated by industry and agriculture. Therefore, good laboratory practices and correct preparation of batch tests are very important for planning of a full-scale biogas plant. The aim of the paper was to determine the effect of mixing in the laboratory batch reactors on the biogas yield of maize straw under thermophilic conditions. The scope of this work included: (1) the analysis of basic physical and chemical parameters and (2) laboratory determination of biogas and methane yield from anaerobic digestion of maize straw with different frequencies of mixing. The obtained biogas and methane yield from the thermophilic fermentation of maize straw mixed every day was $381.89 \mathrm{~m}^{3} \mathrm{Mg}^{-1} \mathrm{FM}$ and $184.97 \mathrm{~m}^{3} \mathrm{Mg}^{-1}$ FM, respectively. The results of this study confirmed the effect of no mixing inside reactors. In the batch test a decrease in biogas and methane yields was observed, by approx. $60 \mathrm{~m}^{3} \mathrm{Mg}^{-1}$ and approx. $28 \mathrm{~m}^{3} \mathrm{Mg}^{-1}$, respectively.
\end{abstract}

Keywords: renewable energy sources, biogas, biogas efficiency, anaerobic digestion test, mixing of substrates

\section{INTRODUCTION}

In recent years, we have observed the increased demand for electricity, heat and conventional fuels. This is caused by the intensive development of civilization and technology in the last century. This in turn, has contributed to the increase in the environmental pollution. However, in the last decades, the interest in renewable energy sources, also including the conversion of biomass to electricity and heat production, has been observed [Wiater and Horysz 2017, Lewicki et al. 2013]. One of the ways of converting biomass into energy is anaerobic digestion (AD) [Czekała et al. 2017]. This process allows obtaining energy as well as fertilizers [Czekała et al. 2015b, Kazimierowicz 2017].

The biogas production in Poland has received a lot of attention due to the potential of agriculture residues that can be converted to biogas [Dach et al. 2014a]. It is estimated that Germany has similar biogas potential as Poland. According to the literature, Poland demonstrates high agricultural potential that comes from the area of 14.5 million hectares, in addition to well-structured and developed cattle, pig and poultry farms. This gives many opportunities for developing agricultural biogas and composting plants [Lewicki et al. 2015]. Therefore, it is crucial to determine the biogas and methane yield from anaerobic digestion (AD) under laboratory conditions prior to full scale biogas production.

$\mathrm{AD}$ is a complex biotechnological process that allows obtaining a product - biogas which is a mixture of methane (45-74\%), carbon dioxide $(25-54 \%)$ and some trace amounts of sulphide, ammonia, hydrogen, nitrogen and oxygen which content do not exceed $1-2 \%$ of the total volume 
[Dach et al. 2014b]. The efficiency of the anaerobic digestion depends on many process parameters such as temperature [Appels et al. 2008], $\mathrm{pH}$ [Ward et al. 2008], C/N ratio [Choong et al. 2016; Mao et al. 2015], hydraulic retention time (HRT) [Choong et al. 2016] and reactor organic load rate (OLR) [Nagao et al. 2012].

The AD research, in the field application of biomass and bio-waste and for its use in such industries as waste water treatment and in agriculture, were studied intensively over the last few decades [Gunaseelan 1997, Chandra et al. 2012a, Appels et al. 2008, Mata-Alvarez et al. 2000, Ward et al. 2008]. Understanding the importance of the process parameters is essential for the optimization of anaerobic digestion and the increase in the biogas and methane yield on an industrial scale [Lindmark et al. 2014, Czekała et al. 2015a].

\section{Mixing during laboratory anaerobic digestion}

Mixing of liquid fraction in the digestion reactors is an important parameter that affects the final biogas yield. [Satjaritanun et al. 2016]. The DIN 38 414-S8 standard is commonly applied for the determination of biogas potential from various substrates [Cieslik et al. 2016, Oslaj et al. 2010, Wellinger et al. 2013]. This standard takes into account the mixing of the eudiometric sets by careful movement of the circular motions [DIN $38414 / \mathrm{S} 8]$. These sets are used by many accredited laboratory units. Unfortunately, due to the uniform construction eudiometric reactors, mixing of their contents can be difficult, which can significantly affect the final result of the biogas and methane yields. One of the solutions could include using sets equipped with a magnetic or mechanical mixing system or reactors to allow accurate manual mixing with an independent gas storage system (fig. 1).

Mechanical stirrers are mainly used in fermentation stations operated in a continuous process [Lindmark et al. 2014, Deublein and Steinhauser 2008]. However, potential problems can be associated with the gas seal placed inside of the stirrer which prevents oxygen from entering the reactor. In this case, it is important to use fermentation sets equipped with an independent gas storage system and the possibility of free manual mixing of the contents. Such reactors were constructed in the Department of Environmental Engineering at the Institute of Biosystems Engineering at Poznan University of Life Sciences (Figure 2).

\section{The aim of the research}

The aim of the paper was to determine the effect of mixing in the laboratory batch reactors on the biogas yield of the maize straw under thermophilic conditions. The scope of this work included: (1) the analysis of basic physical and chemical parameters and (2) the laboratory determination of biogas yield from anaerobic digestion of maize straw with different frequencies of mixing.

\section{MATERIALS AND METHODS}

\section{Research material}

The tested material was maize straw, which was obtained from Przybroda AgriculturalOrchard Experimental Farm belonging to the Poznan University of Life Sciences (PULS). The fermentative inoculum - a liquid fraction obtained after dry mass separator was sampled from

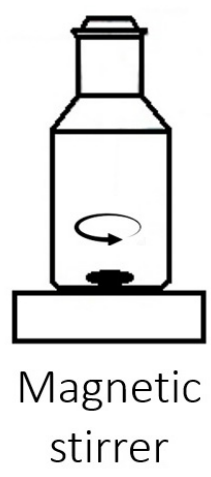

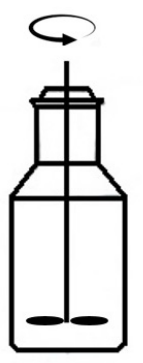

Mechanical stirrer

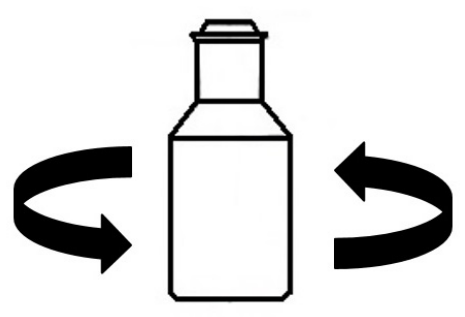

Hand mixing

Fig. 1. Mixing systems for a batch test 


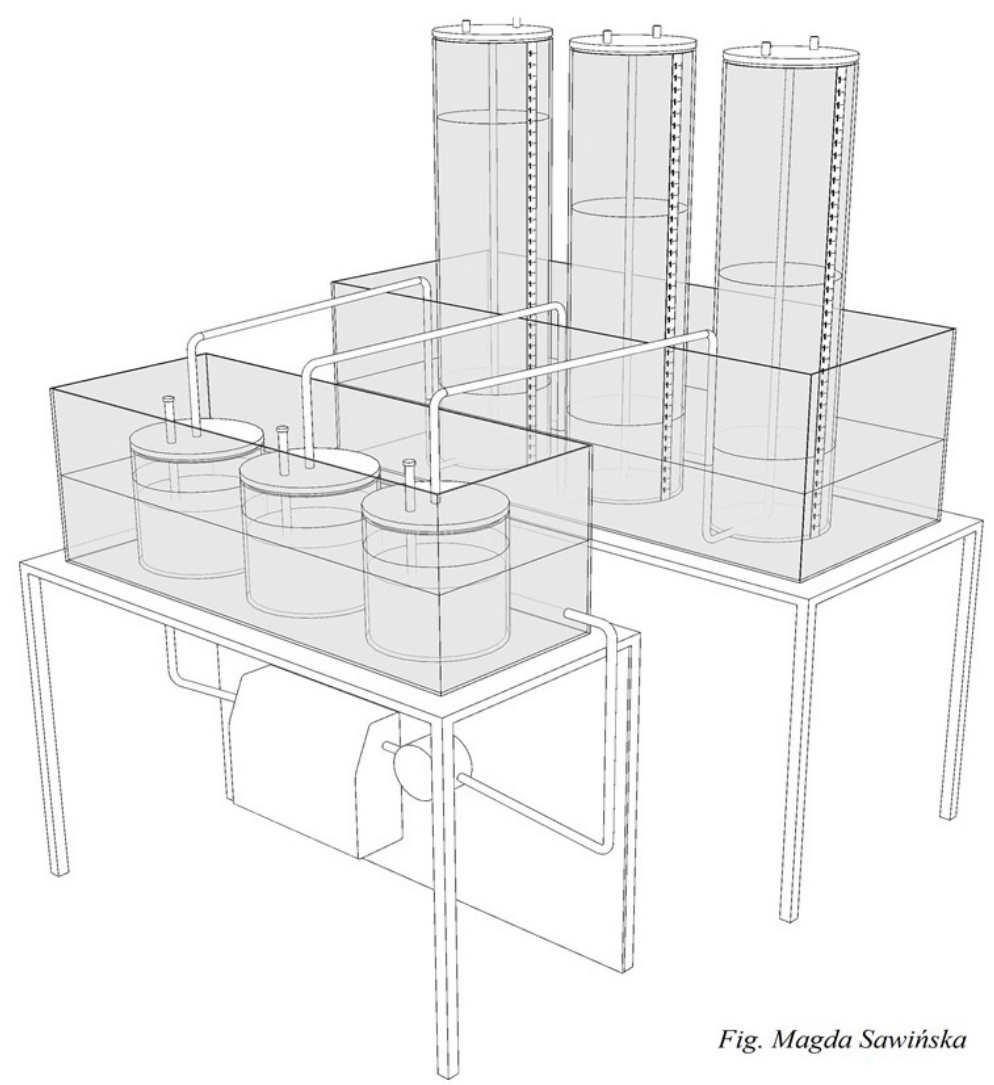

Fig. 2. The set of anaerobic digesters designed, constructed and used in the Laboratory of Ecotechnologies at Poznan University of Life Sciences [Cieślik et al. 2016, Dach et al. 2016]

the operating agricultural biogas plant in Dzialyn (Poland). After sampling from digestate tank, the inoculum was stored under anaerobic conditions at $52^{\circ} \mathrm{C}$ (thermofilic temperature).

\section{Characteristic of maize straw}

The analyses of basic physicochemical parameters of the maize straw and inoculum were conducted according to the Polish standards: total solids (PN-75 C-04616/01), volatile solids (PNZ-15011-3) and pH (PN 90 C-04540/01). These parameters were measured to determine the appropriate ratios of the fermentation mixtures. On the basis of these parameters, the biogas efficiency on $\mathrm{Mg}$ of fresh matter, dry matter and dry organic matter of the substrate was calculated.

\section{Determination of the biogas efficiency}

Determination of the biogas efficiency from the maize straw in batch culture technology (under thermofilic conditions of $52^{\circ} \mathrm{C}$ ) were carried out in the Laboratory of Ecotechnologies at the Institute of Biosystems Engineering at the Poznan University of Life Sciences. It was performed on the basis of internal procedures, based on the adapted standards: DIN 38 414-S8 and VDI 4630 which are commonly used in Europe. Detailed methodology was presented by Cieslik et al. [2016] and Dach et al. [2016, 2014b].

In order to determine the effect of stirring in the reactors on the biogas yield of maize straw, the individual reactors were subjected to circular stirring at different intervals: daily, twice a week (Monday and Thursday) and without mixing throughout the experiment.

\section{RESULTS AND DISCUSSION}

\section{Physical and chemical parameters}

In the first stage of the experiment, basic physical and chemical parameters of the substrate and inoculum were analyzed (Table 1). These parameters were necessary to determine the appropriate fermentation mixtures and subsequent calculations of the biogas yield.

The inoculum used in the experiment was characterized by organic matter in fresh weight of about $2.29 \%$. The total solids and volatile total 
solids content of maize straw used in the experiment were $77.80 \%$ FM and $89.78 \%$ TS, respectively. The determination of basic parameters of substrates is necessary for correct preparation of anaerobic digestion in a continuous test. At this stage, some potential problems with using different substrates can be predicted.

\section{Daily dynamics of biogas and methane production}

The diagrams of daily dynamics of methane production and cumulative production of biogas can show regularity and potential inhibition in the fermentation process. The figure 3 shows the dynamics of methane production in the fermentation reactors. During the process, some differences in the dynamics of gas production were observed, influenced by the mixing frequency in the reactors.

During the thermophilic fermentation, three distinct gas production peaks were observed. They were visible on the $2^{\text {nd }}, 10^{\text {th }}$ and $19^{\text {th }}$ day of the process. The local peaks of biogas production are the result of the chemical composition of the analyzed material. During anaerobic digestion, sugars, proteins and lipids differ in respect to

Table 1. Physical and chemical parameters of maize straw and inoculum.

\begin{tabular}{|c|c|c|c|c|}
\hline Substrate & $\mathrm{pH}$ & $\begin{array}{c}\text { Conductivity } \\
{[\mathrm{mS}]}\end{array}$ & $\begin{array}{c}\text { Total } \\
\text { Solids } \\
{[\%]}\end{array}$ & $\begin{array}{c}\text { Volatile } \\
\text { Solids } \\
{[\% \text { TS }]}\end{array}$ \\
\hline $\begin{array}{c}\text { Maize } \\
\text { straw }\end{array}$ & 9.66 & 1.41 & 77.80 & 89.78 \\
\hline Incoulum & 7.84 & 17.72 & 3.58 & 64.03 \\
\hline
\end{tabular}

the times of decomposition [Cieślik et al. 2016]. During the test, some differences in the intensity of biogas production peaks between the samples were observed. They were particularly visible in the samples mixed twice a week. In the research, the influence of mixing into reactors on shortening the digestion time was not observed. For this purpose, is necessary to carry out additional tests in batch system. According by Lindmark et al. [2014], accurate distribution of microorganisms in fermentation liquid fraction allows for the formation of a consortium of bacteria.

\section{Biogas and methane efficiency}

The determination of biogas and methane yields, in calculated on fresh matter, total solids and volatile solids, is necessary for compare of energetic potential between substrates. The table 2 shows the biogas yield and methane concentration in biogas from the anaerobic digestion of the investigated substrate under thermophilic conditions.

In the process of thermophilic digestion of maize straw mixed every day, (in calculation to $\mathrm{Mg}$ of fresh mass of substrate) $381.89 \mathrm{~m}^{3}$ of biogas with the average methane content of $48.44 \%$ was produced (table 2). Between the daily mixing of samples and reactors, which have been mixed twice a week, no significant reduction of biogas yield was found (for biogas $-6.89 \mathrm{~m}^{3} \cdot \mathrm{Mg}^{-1}$ and for methane only $\left.1.54 \mathrm{~m}^{3} \cdot \mathrm{Mg}^{-1}\right)$. However, in the case of maize straw without mixing, the yields of biogas and methane production were significantly lower by $59.59 \mathrm{~m}^{3} \cdot \mathrm{Mg}^{-1} \mathrm{FM}$ and $27.86 \mathrm{~m}^{3} \cdot \mathrm{Mg}^{-1}$, respectively.

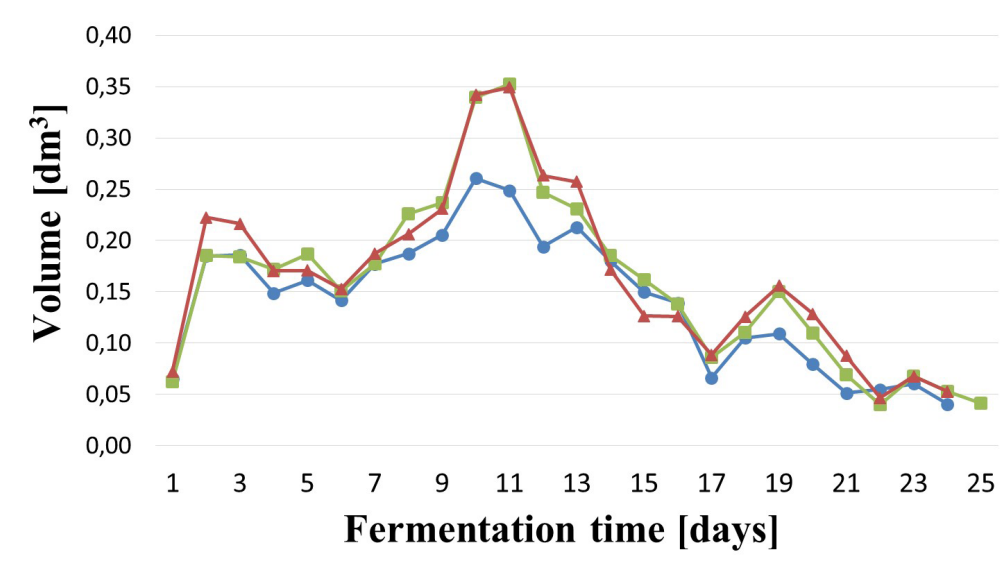

$\rightarrow$ Without mixing $\quad \rightarrow$-Mixing twice a week $\quad ₫$ Daily mixing

Figure 3. Daily dynamics of methane production from reactors 
Table 2. The biogas and methane yield

\begin{tabular}{|c|c|c|c|c|c|c|c|}
\hline \multirow[b]{2}{*}{ Sample } & \multirow[b]{2}{*}{$\begin{array}{c}\text { Methane } \\
{[\%]}\end{array}$} & \multicolumn{2}{|c|}{ Fresh matter } & \multicolumn{2}{|c|}{ Total Solids } & \multicolumn{2}{|c|}{ Volatile Solids } \\
\hline & & $\begin{array}{c}\text { Cumulated } \\
\text { methane } \\
{\left[\mathrm{m}^{3} \cdot \mathrm{Mg}^{-1} \mathrm{FM}\right]}\end{array}$ & $\begin{array}{c}\text { Cumulated } \\
\text { biogas } \\
{\left[\mathrm{m}^{3} \cdot \mathrm{Mg}^{-1} \mathrm{FM}\right]}\end{array}$ & $\begin{array}{c}\text { Cumulated } \\
\text { methane } \\
{\left[\mathrm{m}^{3} \cdot \mathrm{Mg}^{-1} \mathrm{TS}\right]}\end{array}$ & $\begin{array}{c}\text { Cumulated } \\
\text { biogas } \\
{\left[\mathrm{m}^{3} \cdot \mathrm{Mg}^{-1} \mathrm{TS}\right]}\end{array}$ & $\begin{array}{c}\text { Cumulated } \\
\text { methane } \\
{\left[\mathrm{m}^{3} \cdot \mathrm{Mg}^{-1} \mathrm{VS}\right]}\end{array}$ & $\begin{array}{c}\text { Cumulated } \\
\text { biogas } \\
{\left[\mathrm{m}^{3} \cdot \mathrm{Mg}^{-1} \mathrm{VS}\right]}\end{array}$ \\
\hline Daily mixing & 48.44 & 184.97 & 381.89 & 237.76 & 490.86 & 264.82 & 546.73 \\
\hline $\begin{array}{l}\text { Mixing twice } \\
\text { a week }\end{array}$ & 48.92 & 183.43 & 375.00 & 235.77 & 482.00 & 262.61 & 536.87 \\
\hline Without mixing & 48.75 & 157.11 & 322.30 & 201.94 & 414.25 & 224.93 & 461.43 \\
\hline
\end{tabular}

The results of the presented research confirmed that the mixing of the reactors influences the efficient production of biogas [Casey 1986, Kaltschmitt and Hartmann 2001, Lee et al. 1995, Smith et al. 1996]. In the samples without mixing of fermentation liquid, the formation of layers on the surface of the fermentation mixture was observed. It is important to point out that the mass containing methanogenic bacteria is stored in the lower part of the reactor due to higher density, while the substrate is collected in the upper layer [Maurer and Winkler 1980]. However, too intensive mixing of the reactor contents can also have an adverse effect on the fermentation bacteria [Lindmark et al. 2014, Deublein and Steinhauser 2008].

\section{CONCLUSIONS}

1. The research has confirmed the effect of mixing in the fermentation reactor and the increase the biogas and methane yields in the samples which were mixed everyday (approx. 60 $\mathrm{m}^{3} \cdot \mathrm{Mg}^{-1}$ for biogas, and approx. $28 \mathrm{~m}^{3} \cdot \mathrm{Mg}^{-1}$ for methane) when compared to the samples with no mixing.

2. In the fermentation process, the influence of mixing into reactors on shortening the digestion time of the substrate was not observed.

3. Lower biogas yields due to the lack of mixing of reactors during laboratory testing may have a significant impact on the estimation of the economic analysing of the planned real scale investment.

\section{REFERENCES}

1. Appels L., Baeyens J., Degrève J., Dewil R. 2008. Principles and potential of the anaerobic digestion of waste-activated sludge. Prog Energy Combust Sci, 34, 755-781.
2. Casey T.J. 1986. Elsevier App. Sci. Pub. 90-103, London.

3. Chandra R., Takeuchi H., Hasegawa T. 2012. Methane production from lignocellulosic agricultural crop wastes: a review in context to second generation of biofuel production. Renew Sustain Energy Rev, 16, 1462-1476.

4. Choong Y.Y., Norli I., Abdullah A.Z., Yhaya M.F. 2016. Impacts of trace element supplementation on the performance of anaerobic digestion process: A critical review. Bioresource Technology, 209, 369-379.

5. Cieślik M., Dach J., Lewicki A., Smurzyńska A., Janczak D., Pawlicka-Kaczorowska J., Boniecki P., Cyplik P., Czekała W., Jóźwiakowski K. 2016. Methane fermentation of the maize straw silage under meso- and thermophilic conditions. Energy, 115 (2), 1495-1502.

6. Czekała W., Dach J., Dong R., Janczak D., Malińska K., Jóźwiakowski K., Smurzyńska A., Cieślik M. 2017. Composting potential of the solid fraction of digested pulp produced by a biogas plant. Biosystems Engineering 160, 25-29.

7. Czekała W. Dach, J., Czekała J.. 2015a. Operational possibilities of a biogas plant at the brewery under polish conditions. Proceedings of the 2nd International Conference on Energy \& Environment: Bringing Together Engineering and Economics, 520-525.

8. Czekała W., Dach, J., Przybył J., Boniecki P., Lewicki A., Carmona, P.C.R., Janczak D., Waliszewska H., 2015b. The energetic efficiency of solid fraction of digestate pulp from biogas plant in production of solid and gaseous biofuels - a case study of $1 \mathrm{MWel}$ biogas plant in Poland. Proceedings of the 2nd International Conference on Energy \& Environment: Bringing Together Engineering and Economics, 547-553.

9. Dach J., Czekała W., Boniecki P., Lewicki A., Piechota T. 2014a Specialised Internet Tool for Biogas Plant Modelling and Marked Analysing. Advanced Materials Research Vol. 909: 305-310.

10. Dach J., Boniecki P., Przybył J., D. Janczak, A. Lewicki, W. Czekała, K. Witaszek, P.C. Rodriguez Carmona, M. Cieślik. 2014b. Energetic effi- 
ciency analysis of the agricultural biogas plant in $250 \mathrm{~kW}(\mathrm{e})$ experimental installation. Energy, 69, 34-38.

11. Dach J., Koszela K., Boniecki P., Zaborowicz M., Lewicki A., Czekała W., Skwarcz J., Wei Qiao, Piekarska-Boniecka H., Białobrzewski I. 2016. The use of neural modelling to estimate the methane production from slurry fermentation processes. Renewable and Sustainable Energy Reviews 56, 603-610.

12. Deublein D., Steinhauser A. 2008. Biogas from waste and renewable sources: an introduction. WILEY-VCH Verlag GmbH \& Co. KGaA, Weinheim.

13. DIN 38 414. 1985. Bestimmung des Faulverhaltens "Schlamm und Sedimente". Beuth Verlag $\mathrm{GmbH}$, Berlin.

14. Gunaseelan V.N. 1997. Anaerobic digestion of biomass for methane production: a review. Biomass Bioenergy, 13, 83-114.

15. Kaltschmitt M., Hartmann H. 2001. Energie aus Biomasse - Grundlagen, Techniken und Verfahren. Springer Verlag Berlin, Heidelberg, New York.

16. Kazimierowicz J. 2017. Biogas acquisition from selected mixtures of expired food products. Journal of Ecological Engineering, 18 (4), 118-122.

17. Lee S.R., Cho N.K., Maeng W.J., 1995. Using the pressure of biogas created during anaerobic digestion as the source of mixing power. Journal of Fermentation Bioenineering., 80 (4), 415-417.

18. Lewicki A., Carmona, P.C.R., Dach, J., Boniecki, P., Janczak, D., Czekala, W., Cieslik, M., Przybył, J. 2015. Energetic aspects of food waste used as an alternative substrates for biogas plant, Proceedings Of The 2nd International Conference On Energy \& Environment: Bringing Together Engineering and Economics, ICEE International Conference on Energy \& Environment, 714-720.

19. Lewicki A., Dach J., Janczak D., Czekała W., 2013 The Experimental Macro Photoreactor for Microalgae Production. Procedia Technology, 8, 622-627.

20. Lindmark J., Thorin E., Fdhila R.B., Dahlquista E.
2014. Effects of mixing on the result of anaerobic digestion: Review. Renewable and Sustainable Energy Reviews 40, 1030-1047.

21. Mao C., Feng Y., Wang X., Ren G. 2015. Review on Research Achievements of Biogas from Anaerobic Digestion. Renewable and Sustainable Energy Reviews, 45, 540-555.

22. Mata-Alvarez J., Macé S., Llabrés P. 2000. Anaerobic digestion of organic solid wastes. An overview of research achievements and perspectives. Bioresour Technol, 74, 3-16.

23. Maurer M. Winkler J-P. 1980. Biogas - Theoretische Grundlagen, Bau und Betrieb von Anlagen. Verlag C.F. Müller. Karlsruhe.

24. Nagao N., Tajima N., Kawai M., Niwa C., Kurosawa N., Matsuyama T., Yusoff M.F., Toda T. 2012. Maximum organic loading rate for the single-stage wet anaerobic digestion of food waste. Bioresour. Technol., 118, 210-218.

25. Oslaj M., Mursec B., Vindis P. 2010. Biogas production from maize hybrids. Biomass and Bioenergy, 34, 1538-1545.

26. Satjaritanun P., Khunatorn Y., Vorayos N., Shimpalee S., Bringley E. 2016. Numerical analysis of the mixing characteristic for napier grass in the continuous stirring tank reactor for biogas production. Biomass and Bioenergy, 86, 53-64.

27. Smith L.C., Elliot D.J., James A. 1996. Mixing in upflow anaerobic filters and its influence on performance and scale-up. Wat. Res., 30 (12), 3061-3073.

28. Ward A.J., Hobbs P.J., Holliman P.J., Jones D.L. 2008. Optimisation of the anaerobic digestion of agricultural resources. Bioresour Technol, 99, 7928-7940.

29. Wellinger A., Murphy J., Baxter D. 2013. The biogas handbook. Sciance, production and applications, Woodhead Publishing Limited 2013.

30. Wiater J., Horysz M. 2017. Organic waste as a substrat in biogas production. Journal of Ecological Engineering, 18, 5, 226-234. 